\title{
Initial antimicrobial management of sepsis: increased prehospital blood lactate levels for identifying sicker patients who may benefit from prehospital antibiotic therapy initiation
}

\author{
Romain Jouffroy ${ }^{1 *}$ (1) and Benoit Vivien ${ }^{2}$
}

To the Editor:

We read with great interest the recent review published in the Journal by Niederman et al. [1] emphasizing that immediate, empiric, broad-spectrum antibiotic therapy to severe sepsis and/or shock patients reduces mortality, despite the fact that it can lead to antimicrobial overuse and resistance; and should be accompanied by an early de-escalation and antimicrobial stewardship.

Early sepsis recognition and appropriate treatment initiation, mainly antibiotic therapy and hemodynamic optimization, are cornerstones for management of septic patients, especially the sicker ones, to improve prognosis $[2,3]$. As underlined by Niederman et al. [1], sepsis occurs commonly outside the hospital environment in $70 \%$ of cases [4], requiring either ambulatory treatment or hospital admission for the most severe form. Nevertheless, for the latter, antibiotic therapy and hemodynamic optimization will only be initiated in the emergency department. With the exception of the most severe cases for which the diagnosis is obvious, e.g., purpura fulminans or patients with low blood pressure and skin mottling in a sepsis context, sepsis diagnose, and severity assessment remain a daily challenge in the prehospital field. For those

\footnotetext{
*Correspondence: romain.jouffroy@aphp.fr

1 Service de Médecine Intensive Réanimation, Hôpital Universitaire

Ambroise Paré, Assistance Publique - Hôpitaux de Paris, Paris Saclay University, Boulogne Billancourt, France

Full list of author information is available at the end of the article
}

patients, we suggest using the point of care (POC) lactate measurement. On the one hand, blood lactate level is a criterion for septic shock diagnosis and is associated with poorer outcome among septic shock patients [3]. On the other hand, POC lactate measurement devices have been validated in the prehospital environment [5]. Therefore, we suggest that a prehospital sepsis severity assessment strategy based on blood lactate level POC assessment may be helpful in identifying the sicker septic patients, i.e., those for whom, in order to reduce sepsis related mortality, prehospital antibiotic therapy instauration cannot wait until hospital admission and should be initiated from the point of prehospital care.

\section{Acknowledgements}

None.

Authors' contributions

$\mathrm{RJ}$ and BV wrote and revised the manuscript. Both authors read and approved the final manuscript.

Funding

None.

Availability of data and materials

Not applicable.

\section{Declarations}

Ethics approval and consent to participate Not applicable.

Consent for publication

$\mathrm{RJ}$ and BV consent for publication. original author(s) and the source, provide a link to the Creative Commons licence, and indicate if changes were made. The images or other third party material in this article are included in the article's Creative Commons licence, unless indicated otherwise in a credit line to the material. If material is not included in the article's Creative Commons licence and your intended use is not permitted by statutory regulation or exceeds the permitted use, you will need to obtain permission directly from the copyright holder. To view a copy of this licence, visit http://creativecommons.org/licenses/by/4.0/. The Creative Commons Public Domain Dedication waiver (http://creativeco mmons.org/publicdomain/zero/1.0/) applies to the data made available in this article, unless otherwise stated in a credit line to the data. 


\section{Competing interests}

The authors declare that they have no competing interests.

\section{Author details}

${ }^{1}$ Service de Médecine Intensive Réanimation, Hôpital Universitaire Ambroise Paré, Assistance Publique - Hôpitaux de Paris, Paris Saclay University, Boulogne Billancourt, France. ${ }^{2}$ SAMU de Paris, Service d'Anesthésie Réanimation, Hôpital Universitaire Necker - Enfants Malades, Assistance Publique - Hôpitaux de Paris, Université de Paris, Paris, France.

Received: 7 October 2021 Accepted: 21 October 2021

Published online: 30 October 2021

\section{References}

1. Niederman MS, Baron RM, Bouadma L, Calendra T, Daneman N,

DeWaele J, et al. Initial antimicrobial management of sepsis. Crit Care. 2021:25:25307.
2. Vincent JL. Antibiotic administration in the ambulance? Lancet Respir Med. 2018;6(1):5-6.

3. Rhodes A, Evans LE, Alhazzani W, Levy MM, Antonelli M, Ferrer R, et al. Surviving sepsis campaign: international guidelines for management of sepsis and septic shock: 2016. Intensive Care Med. 2017:43(3):304-77.

4. Esteban A, Frutos-Vivar F, Ferguson ND, Penuelas O, Lorente JA, Gordo F, et al. Sepsis incidence and outcome: contrasting the intensive care unit with the hospital ward. Crit Care Med. 2007;35(5):1284-9.

5. Léguillier T, Jouffroy R, Boisson M, Boussaroque A, Chenevier-Gobeaux C, Chaabouni T, et al. Lactate POCT in mobile intensive care units for septic patients? A comparison of capillary blood method versus venous blood and plasma-based reference methods. Clin Biochem. 2018;55:9-14.

\section{Publisher's Note}

Springer Nature remains neutral with regard to jurisdictional claims in published maps and institutional affiliations.
Ready to submit your research? Choose BMC and benefit from:

- fast, convenient online submission

- thorough peer review by experienced researchers in your field

- rapid publication on acceptance

- support for research data, including large and complex data types

- gold Open Access which fosters wider collaboration and increased citations

- maximum visibility for your research: over 100M website views per year

At BMC, research is always in progress.

Learn more biomedcentral.com/submissions 